\title{
CONCEPT AND APPLICATION OF AKAD WAKALAH IN MURABAHA FINANCING IN ISLAMIC BANKING (A COMPARATIVE STUDY BETWEEN INDONESIA AND MALAYSIA)
}

\author{
Bagya Agung Prabowo \& Jasri Bin Jamal \\ Faculty of Law The National University of Malaysia \\ Selangor, Darul Ehsan, Malaysia \\ bagya.agung@uii.ac.id; jasri@ukm.edu.my
}

\begin{abstract}
Islamic banks have grown stronger by continuing to provide innovative products and services to successfully increase the number of customers. So far, the majority of financing by Islamic banks controlled by murabaha financing almost $80 \%$ 95\%. In the bank's murabaha scheme as the seller (ba'i) to purchase necessary items and then resell it to customers, clients (musytari) with a sales price equivalent to the purchase price and profitability of banks. In reality, Islamic banks using wakalah empower customers to purchase their goods. Step wakalah apply concepts to customers is unwise because MUI Fatwa No.04 / DSN-MUI / IV / 2000 has determined that the sale of murabaha contracts made after the goods become the property of Islamic banking principles. The main problem in Indonesia is that there are legal provisions that are not in harmony and not based on actual consumer rights. It is geared toward legal uncertainty. To overcome various problems, this research adopted the method of analysis based on doctrinal content, by implementing four types of approaches to the law, namely: (i) history / historical; (ii) Jurisprudence / philosophy; (iii) comparison; and (iv) analytical and critical. In addition, harmonized approach is also necessary for legislative alignment with Islamic philosophy and the philosophy of consumer protection. By making Malaysia as a reference, this thesis aims to identify the application wakalah perspective and consumer protection improvement in Indonesia. In addition to this, the restructuring of the existing system in Indonesia is required by legislation harmony, improvement and diversification of institutional oversight mechanisms Islamic banking operations.
\end{abstract}

Keywords: Wakalah, Murabaha Financing, Consumer Protection 1. Introduction

\subsection{Background}


The development of Islamic banking in Indonesia is so fast and quick, but some people still exist who believe that Islamic banks, conventional banks are using Islamic terms to lure the Muslim community. For example, a contract which commenced sentences Bismillahirrahmaanirrahiim and workers who wear Muslim clothing and say hello. However, there is still criticism that the implementation of the agreement on Islamic banks still use methods prohibited by sharia. No doubt the public about Islamic banking is inevitable because the banking connotation over the years are distinctly separated by sharia, until the beginning of the establishment of Islamic banks, many do not believe in the success of the Islamic economic experts in consolidating the banking institutions with sharia. ${ }^{1}$

The challenges faced in developing the Islamic financial system as in the context of the theory, operation and implementation. ${ }^{2}$ In terms of theoretical, philosophical and financial systems function on the basis of the distribution of profits and losses (profit-loss sharing) should be developed. In operation, the necessary attention to innovation, intermediation, discipline and risk control, while in the context of the implementation of the system is required application must be adapted to the legal and economic situation of the community in mind. In fact, Islamic banking operation on the scale of an efficient system to date, limited by the problems in the economy, such as the lack of a strong monitoring framework and rigorous regulatory system in the financial system. ${ }^{3}$

One of the activities of Islamic banking is channeling funds through murabaha financing products. Murabaha is the sale of goods at the original price with the added advantage that has been agreed. Features murabaha is the seller must inform the buyer of the product purchase price and to state the amount of

${ }^{1}$ Ascarya, Akad dan Produk Bank Syariah, Raja Grafindo Persada, Jakarta, 2007, pp. 206

${ }^{2}$ Zamir Iqbal, Abbas Mirakhor, Pengantar Keuangan Islam: Teori dan Amalan. terj. oleh A.K. Anwar, Prenada Media Group, Jakarta, 2008, pp. 373

${ }^{3}$ Azis Budi Setiawan, Jurnal Koordinat, 8, 2016, pp.2 
profit added to the cost. ${ }^{4}$ The foundation that allows the practice of Islamic murabaha is the Qur'an, An-Nisa ': 29,

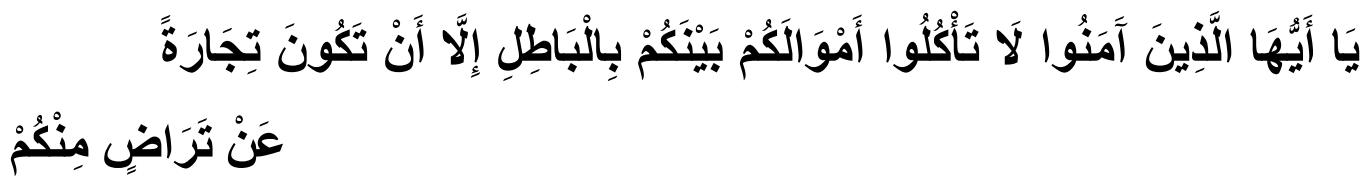

Which means: "O you who believe! Do not devour your property among yourselves in vanity, except by way of business based on the willingness of you."

In Islam there is also the priority order of kaffah (comprehensive) in the practice of religion. Based on these things, so in the context of Islamic banking practices also require integrated with syariah services as a whole. Thus, starting from the product of manufacturing activities or the time of transaction must be ensured throughout the process is in line with sharia Islamic law in order to avoid the problem of non-compliance '.

\subsection{Statement of the Problem}

In the context of this research, three main problems concerning application of the concept wakalah in murabaha financing in Islamic banking to be studied are: first, the book that became the legal foundation for the practice wakalah in murabaha financing in Islamic banking; second, an institution that works to protect consumers bank; and third, supervision institutions of Islamic banking operations. Details of these three problems is as shown in figure 1.1 below:

\footnotetext{
${ }^{4}$ Wiroso. Jual-beli Murabahah, UII Press, Yogyakarta, 2005, pp. 16
} 


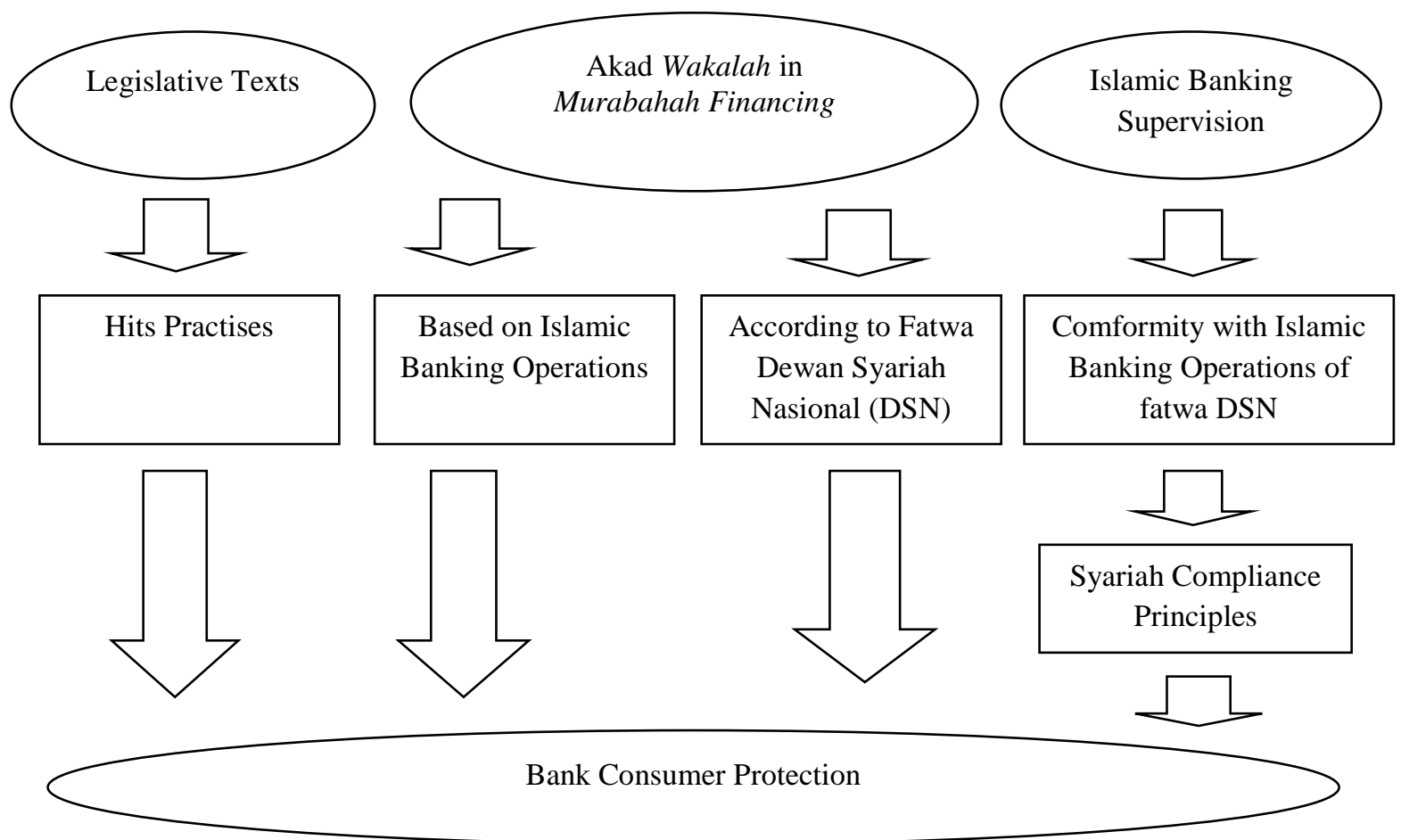

Figure 1.1: The issue of consumer protection in relation to the application akad wakalah in murabaha financing

Islamic banking was developed based on the needs of the Muslim community for banking services in line with the Sharia. According to the Islamic concept, the mutual relations of the bank with the bank as a 'partner' in a position of balance. ${ }^{5}$ But in reality, the bank was very weak position when faced with the bankers, so that should be protected by law.

In principle, Islamic banks can not give money in cash to the bank, but through financing. One is through murabaha financing products, namely the sale of goods at the original price with the added advantage that has been agreed. Users

${ }^{5}$ Sutan Remy Sjahdeini, Perbankan Islam dan Kedudukanya dalam Tata Hukum Perbankan Indonesia, Pustaka Utama Grafiti, Jakarta, 1999, pp. 162 
banks as buyers (Jupiter) requesting bank as the seller (Ba'i) represents wakalah buy goods through the bank and return to pay by installments. ${ }^{6}$

The reality is that in practice there murabaha financing issues that are not in line with the tenets of sale murabaha, the bank provides cash and delegate users with wakalah to make purchases of its own preferred to the supplier. Users return to pay for the credit, so it looks identical to conventional banking credit is forbidden in Islamic law. This situation appears to conflict because the MUI Fatwa No.04 / DSN-MUI / IV / 2000 has determined that the sale of murabaha contracts made after the goods become the property of Islamic banking principles. Purchase of goods shall be that which exists and is wholly owned by the selling party during the contract of sale. Therefore, the sale of which do not exist physically, is not owned by the selling party is invalid. In reality, this happens because there is no bank that dared to write in their financial statements that the bank had assets and then sell them to customers. This is because banks in Indonesia is functioning as intermediaries (financial intermediary). In other words, the bank is providing financing, rather than buying the items, and then resold. Due to the binding regulations, banks are not allowed to practice practical commercial. With this provision, the bank may not be able to buy the necessary goods a customer on behalf of the bank itself. Thus, the bank had violated Islamic principles based on the DSN MUI fatwa.

Among other implications that arises is, if the item is defective or hidden disgrace, it is as if the responsibility can not be accepted by the bank. In practice the bank (as consumers of banking services) are not protected by law, although there was a Law 8 of 1999 on Consumer Protection. The reality monitoring mechanism by the Sharia Supervisory Board (DPS) on adherence to Islamic principles more needs to be rectified, despite the Law 21 of 2008 concerning Islamic Banking and National Sharia Board Fatwa (DSN) on Murabahah. Things

${ }^{6}$ Zaenuddin Ali, Hukum Perbankan Syariah, Sinar Grafika, Jakarta, 2008, pp. 36 
such as the degradation to which the user needs to get proper bank can be summarized as shown in Figure 1.2 below:

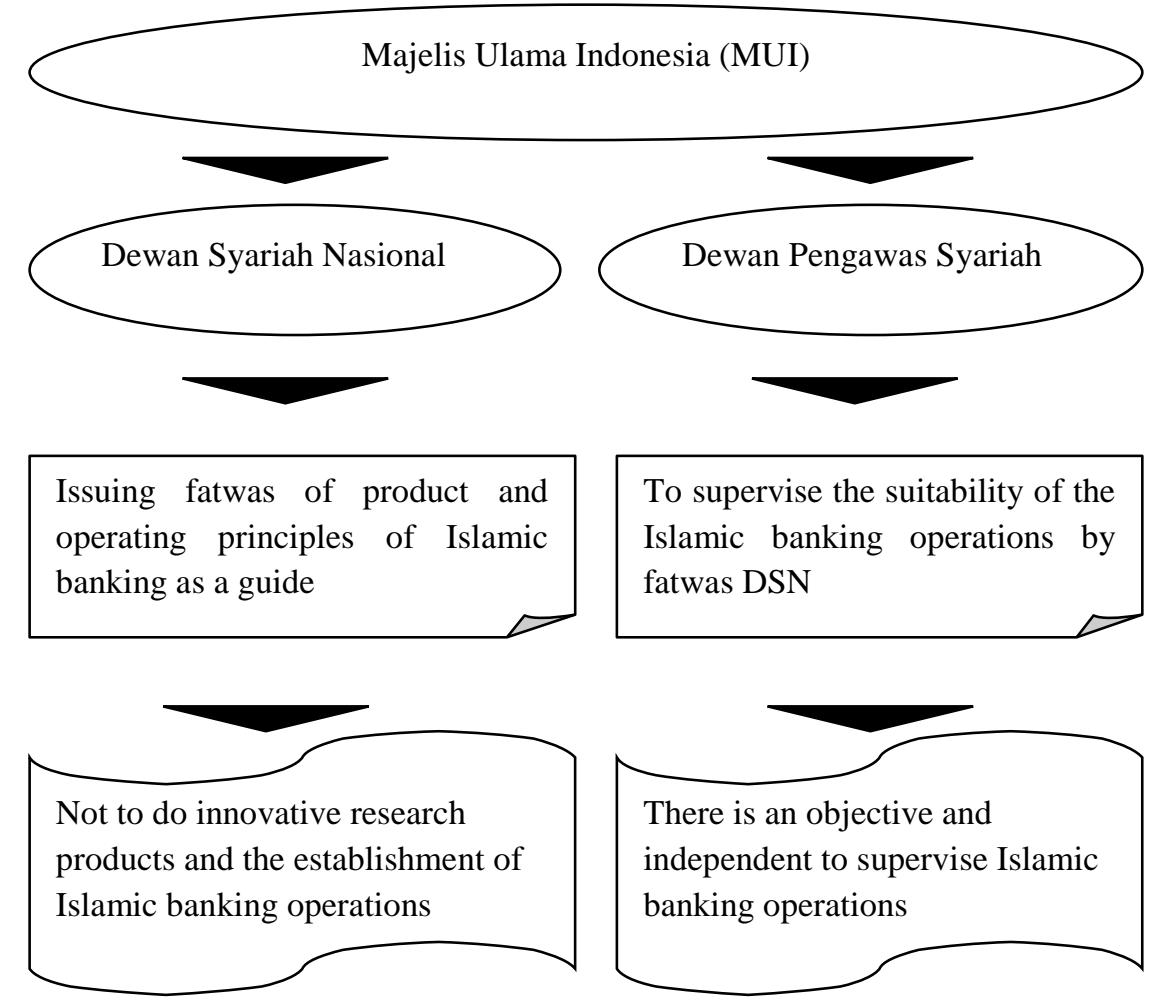

Figure 1.2: The problem of institutions related applications wakalah in murabaha financing in Islamic banking

\subsection{Research Questions}

In this research, three key issues regarding the application of the concept wakalah in murabaha financing in Islamic banking which will be examined are:

1. Is the concept and application wakalah in murabaha financing in Islamic banking in line with Islamic principles?

2. How is monitoring of the application wakalah in murabaha financing?

3. How does the consumer protection murabaha financing bank to apply wakalah? 


\subsection{Objectives of Study}

This research focuses on the problems that exist in the application wakalah in murabaha financing. For ease of discussion, the overall objective of this research is divided into two categories:

General objectives:

Overall objective of this research is to print out the application wakalah in financing murabaha Islamic banking perspective on consumer protection Specific Objectives:

1. Identify the extent of the concept and application wakalah in murabaha financing in Islamic banking in line with Islamic principles

2. To propose the restructuring of the system of supervision of the application wakalah in perspective murabaha financing bank consumer protection; and

3. Compare the user application wakalah Islamic banking in Malaysia and Indonesia as the country elected perpective consumer protection

\section{Research Methods}

Research will be conducted this research is the law where the law, the relevant statutory and case become the primary source. In other terms, such methods can also be called as a doctrinal or theoretical studies. ${ }^{7}$

Legal research using methods generally apply doctrinal four-pronged approach: i) the history / histories; ii) jurisprudence / philosophy; iii) comparison; and iv) an analytical and critical: ${ }^{8}$

Historical approach / History:

1. Used to determine how and why the existing regulations were adopted at that. ${ }^{9}$

${ }^{7}$ Yakin Anwarul, Legal Research and Writing, Lexis Nexis, Kelana Jaya, 1992, pp.10

${ }^{8}$ Sakina Shaikh Ahmad Yusoff, Graduate Thesis Proposal Preparation, New Graduate Program Modification Know Sem. II Session 2002/2003. 2002

${ }^{9}$ D.M. Walker, The Scottish Legal System an Introduction to the Study of Scots Law. 6 eds, W Green/Sweet \& Maxwell, Edinburg, 1992, pp.6 
2. Aiming to identify its onset and progression of certain legal review. It is the method of detection, evaluation and synthesis of evidence and the evidence objectively and systematically to obtain the facts and concluded that the earlier incidents related. ${ }^{10}$

3. The work of academic, public documents, journal writing, seminar papers, law reports and more also completed the process of collecting data for this method.

Jurisprudence approach / philosophy:

1. Examination of the ideas, theories and techniques peeled legal basis of current knowledge in multiple disciplines, is a set of related legal theory, a wellstructured and systematic study of basic principles of law in the form of large, a scientific first principles exist in the legislation, is a fundamental concept and principles as a fundamental and central to the proposition of a law. ${ }^{11}$

2. Contributing latest idea in answering questions related to the early principles of law, theory and set of laws provisions. Therefore this approach is used to study philosophy wakalah application in murabaha financing, Islamic banking supervision and consumer protection in the perspective of Islamic banks.

Comparative Approach:

1. To identify the pros and cons of an old legal principle on a new legal system. In addition, this study seeks to examine the differences and similarities between two or more different legal systems

2. To see the truth in things, we should also look through the eyes of a foreigner by a certain distance, which is a complicated condition to be achieved through national phenomenon itself. For this reason, the comparative law is an

${ }^{10}$ Mahdi Zahraa, Research Methods for Law Postgraduate Student Overseas, Stilglow, Kuala Lumpur, 1998, pp.30.

${ }^{11}$ D.M. Walker, The Scottish Legal System an Introduction to the Study of Scots Law. 6 eds, W Green/Sweet \& Maxwell, Edinburg, 1992, pp. 51 
important element (Lepaulle, 1992, The Functions of comparative law, Harv Law Review 853) ${ }^{12}$

3. The comparative approach is needed in this research as a way to get wakalah application model is better than the selected countries.

4. In this research references from selected countries is needed. Countries selected for comparison purposes is Malaysia. The rational choice based on a few of them; (i) Malaysia is a country that made Islam the official religion, means justify the use of the remaining Islamic law; (ii) The majority of the population is Muslim; and (iii) have a legal system related to Islamic banking, which has a longer operating out of Indonesia. Based on these experiences, Malaysia has had a system that takes into account the interests of consumers Muslim bank which comply with Islamic principles.

5. Approaches such comparisons can renew and refresh the research on the application of the concept wakalah in murabaha financing and development worldwide.

Analytical and Critical Approaches:

1. A researcher can review and provide any suggestions for modifications, cancellation and replacement of law is weak and ineffective. ${ }^{13}$

2. The real problem is identified that can be carried out efforts to prevent it, and make improvements to the concept and application wakalah in murabaha financing in Islamic banking has so far failed to give protection to the interests of consumers.

3. Accomplish almost in all chapters in this thesis, complementing other approaches are also used in each chapter so as to formulate the direction of improvement

\footnotetext{
${ }^{12}$ Lepaulle, The Functions of Comparative Law (1922) 35, Harv. Law. Review 1992, pp. 853

${ }^{13}$ Chartterjee, Methods of Research in Law, Old Bailey Press, London, 2000, pp. 38
} 
4. Research is using two main techniques of data collection, namely the study of literature and field studies

\section{Literatur Review}

Research that brings the three areas of study, namely the concept and application wakalah in financing murabaha, Islamic banking supervision and consumer protection is nothing new and has never existed either in Indonesia or Malaysia. Therefore, research in this area, are nearly nonexistent. Since all three of these aspects have a wide scope of the study, it mostly does not relate to other aspects.

In a murabaha financing aspects, there are few studies about the past, but the number is less than the study of wakalah in murabaha financing. Similarly, research on supervision on products murabaha Islamic banking and consumer protection bank. Based on a search of the author on the research results that already exist, to review the concept and application of wakalah in murabaha Islamic banking; a comparative study between Indonesia and Malaysia has never been done in the same topics and issues. The authors found some research on past murabaha financing which has similarities and differences in it. Here are some of the previous studies that show the authenticity of this research:

Muhammad Hafidh in 2014 has conducted research entitled "Reconstruction of Filling Deed of Murabaha Islamic Banking Based on the Teachings of Islam and the Values of Justice". ${ }^{14}$ Results of research on the implementation of Islamic values and the values of justice, fully reflects the content of the deed by the notary for the murabaha Islamic banking in Indonesia. It can be seen from the existence of a number of issues of irregularities, where there is a

14 M. Hafidh, Rekonstruksi Isi Akta Notaris Perbankan Syariah untuk Murabahah Berdasarkan Nilai Ajaran Islam dan Nilai Keadilan, Ph.D Thesis, Universitas Islam Sultan Agung, Indonesia, 2014 
change in the basis of buying and selling a murabaha as that of conventional banks in lending interest calculation.

Razli Ramli, Mohammad Khairi Currently, Haryani Aminuddin in 2014 has conducted research entitled Islamic Banking Practices from the Practitioner's Perspective. ${ }^{15}$ Results of research on wakalah an agency contract. Savings account, the contract is most suitable for the purpose of saving is to save money and to appoint bank to manage the funds for them. When wakalah used in a savings account, a depositor would keep their savings and appoint an agent to manage their funds.

Muhamad Nadratuzzaman in 2013 has been doing research on "Islamic Financial Products in Indonesia and Malaysia." ${ }^{16}$ Results of research on compared with conventional banks, Islamic banks not only offer differences in principle of operation of the principle of sharing in it but also integrate the justice in any transaction, uphold the principle of balance and harmony, ethics and moral in investing, as well as the principles kemaanfaatan, unity, brotherhood and universal benefits for all parties involved. Islamic banks are very careful in managing their finances, thus avoiding speculative actions, Shariah prohibited monopoly in the transaction.

Renny Supriyatni Bachro in 2011 has conducted research entitled "Agreement for Financing the Sharia result in a Fair as part of efforts to develop Islamic Banking". ${ }^{17}$ The results of his research found the concept of profit sharing in the financing agreement sharia use profit and loss sharing mechanism because it contains dimensional distribution of justice and sharing the same business. Netti Sumiati in 2010 has conducted research on "juridical analysis of the

15 R. Ramli, M. K. Saat, Haryani Aminuddin, Islamic Banking Practices from the Practitioner's Perspective, Thesis, Not in Published, 2014

${ }^{16}$ M. Nadratuzzaman, Produk Kewangan Islam di Indonesia dan Malaysia, Thesis, Not in Published, 2013

17 Renny Supriyatni Bachro, Perjanjian Bagi Hasil dalam Pembiayaan Syariah yang Berkeadilan sebagai Salah Satu Upaya Pengembangan Bank Syariah, Thesis, Not in Published, 2011 
Financing Agreement with the Islamic Banking System; Murabaha, Musharaka and Mudaraba". ${ }^{18}$ The results of the implementation of its research on Islamic banking financing agreement irregularities still occur, especially in the murabaha agreement

Dyah Susanti Ochtorina in 2010 has conducted research entitled "Basis of Justice in accordance with the Agreement Musharaka Agreement on the Establishment of the Company". ${ }^{19}$ The results of his research to realize the principles of fairness in contracts Musharaka can be found in the nature of capital, determination of gains and losses in parts of contracts, management and termination of the contract musharaka.

Kiky Noerma Puttiani in 2010 has conducted research entitled "The role of the notary in the Agreement Establishing Act Funding For Lending at Bank; Review of the Financing Agreement with Bank Muamalat Indonesia”. ${ }^{20}$ The results of his research found the financing agreement is an agreement between the bank based on sharia principles with others to fund our business activities, or other activities specified in accordance with sharia Ah. Azharuddin Lathif in 2010 has conducted an investigation entitled "Draft Application Murabaha contract on Islamic Banking in Indonesia”. ${ }^{21}$ Her work, which is one type of murabaha sale of a mandate, then it is very broad and general nature of which in Islamic law is the main contract scheme used in the practice of Islamic banking in Indonesia. But in practice, murabaha has undergone many modifications and incorporated the basic concept that exists in classical fiqh Muamalat.

18 Netti Sumiyati, Analisis Yuridis terhadap Perjanjian Pembiayaan dengan Sistem Perbankan Syariah; Murabahah, Musyarakah, dan Mudharabah, Thesis, Not in Published, 2010

${ }^{19}$ Dyah Susanti Ochtorina, Asas Keadilan dalam Perjanjian Berdasarkan Akad Musyarakah pada Pembentukan Perusahaan, Thesis, Not in Published, 2010

${ }^{20}$ Kiky Noerma Puttiani, Peranan Notaris dalam Membuat Akta Akad Pembiayaan Bagi Pemberian Kredit pada Bank Syariah; Penelaah terhadap Akad Pembiayaan di Bank Muamalat Indonesia, Thesis, Not in Published, 2010

${ }^{21}$ Ah. Azharuddin Lathif, Konsep Aplikasi Akad Murabahah pada Perbankan Syariah di Indonesia, UIN Jakarta Press, Jakarta 2010. pp. 5 
Zaharuddin Abd Rahman in 2009 had conducted research entitled "Murabaha: Theory, Applications and Issues in Current Islamic Banking". ${ }^{22} \mathrm{Her}$ work reveals a concept of murabaha sales is one of the earliest concept developed and popularized by the Islamic banking sector in Malaysia and the world in general. However, in order to implement this concept precisely that according to the fatwas issued by authoritative bodies, several obstacles and challenges arise, so find undermine public confidence in the effectiveness. Finally, more and more confused with Islamic banking products and even some doubted the Sharia compliance of the product.

Based on the above, it can be seen that there are some similarities and differences between previous research by the authors research. The equation in this case related to the aspects studied equation, namely on financing in Islamic banking. Although there are no major differences in the previous investigation but at issue in the investigation of the author's concept and application wakalah in murabaha financing in Islamic banking. The main essence of the author's research is the need to find concepts and applications wakalah in murabaha financing, making it more in line with Islamic principles. This difference shows where the author has research authenticity because it contains new things in it.

\section{Conclusion}

Islamic banking is a business institution which has special characteristics different from conventional banking. Islamic banking users also have different requirements, especially related to the concept and application wakalah in murabaha financing. Therefore, a comprehensive study is needed to bring together these three great concepts that apply wakalah in murabaha financing in Islamic banking in line with Islamic principles, mechanisms controlling the operation wakalah in murabaha financing and consumer protection against bank financing

${ }^{22}$ Zaharuddin Abd Rahman, Murabahah Teori, Aplikasi \& Isu Dalam Perbankan Islam Semasa, True Wealth Publishing, Selangor, 2009, pp. 39 
murabaha contract applications wakalah. The need of looking at this from the perspective of consumer protection because Islamic banking users is also part of consumers that meet generally weaker position than traders. Concerned about the weak position of such users is applicable in all countries. This is due to the tendency of imbalance between the position of consumers against traders that occur in any place.

Basically, most of the problems associated with the concept and application wakalah in murabaha financing in Islamic banking because of lack of understanding and awareness of consumer rights for real. It is also caused by an inaccurate perspective in view of users, because not using an integrated approach to Islamic banking between compliance with the principles of sharia, Islamic banking operations oversight mechanisms and consumer protection. This has led to confusion continued.

Harmonization of legal approaches used to find harmony between the rights of users of Islamic banking that is set up provisions in existing legislation with the philosophy of Islam is correct. Some of the legislation relating to the rights of bank users, in particular with regard to the application wakalah in murabaha financing a number of provisions that are not in harmony with the philosophy of Islamic banking. Therefore, it is necessary to harmonize efforts to re-provision.

\section{References}

\section{A. Books}

Abdul Ghofur Anshori. 2010. Perbankan Syariah di Indonesia. Gadjah Mada University Press. Yogyakarta

Abdullah As-Sa'idi. Ar-Riba fil Mu'amalat Al-Mashrafiyah Al-Mu'ashirah, 2/1017-1020

Abdullah bin Muhammad bin Ahmad al-Tayyar. 2006. Al-Bunuk al-Islamiyah Bayna al-Nazariyyah wa al-Tatbiq. Cet.2, Dar alWan. Riyadh. 1414 H, dalam Hadenan Towpek. Joni Tamkin

Abdullah M. Noman. 2003. Imperatives of Financial Innovations For Islamic Banks' in International Journal of Islamic Financial Services 3 
Abdullah Saeed. 2003. Bank Islam dan Bunga, Studi Kritis dan Interprestasi Kontemporer tentang Riba dan Bunga. Ctk. Pertama. Pustaka Pelajar. Yogyakarta . 2004. Menyoal Bank Syariah: Kritik atas Interpretasi Bunga Bank Kaum Neo-Revivalis. Paramadina. Jakarta

Adiwarman Karim. 2004. Bank Islam Analisis Fiqh dan Keuangan. RajaGrafindo. Jakarta

Ahmad Azhar Basyir. 2004. Asas-asas Hukum Muamalat (Hukum Perdata Islam). UII Press. Yogyakarta

Ahmad Sunawari Long. 2014. Metodologi Penyelidikan Pengajian Islam: Universiti Kebangsaan Malaysia. Bangi

Anwarul Yakin. 1992. Legal Research and Writing. Lexis Nexis. Kelana Jaya Ascarya. 2007. Akad dan Produk Bank Syariah. RajaGrafindo Persada. Jakarta

Aziz Budi Setiawan. Perbankan Syariah; Challenges dan Opportunity untuk Pengembangan di Indonesia, Jurnal Kordinat, Edisi: Vol.VIII No.1, April 2006

Bagya Agung Prabowo. 2012. Aspek Hukum Pembiayaan Murabahah pada Perbankan Syariah. UII Press. Yogyakarta

Bailey Kenneth. 1982. Kaedah Penyelidikan Sosial (terj.) Hashim awing: Dewan Bahasa dan Pustaka. Kuala Lumpur

Chartterjee. 2000. Methods of Research in Law. Old Bailey Press. London

D.M. Walker. 1992. The Scottish Legal Sistem. W. Green/Sweet \& Maxwell. Edinburg. Sixth Edition. Revised

Edy Wibowo dan Untung Hendy. 200. Mengapa Memilih Bank Syariah. Ctk. Pertama. Ghalia Indonesia. Bogor Selatan

Fuad al-Omar dan Muhamad Abdel-Haq. 1996. Islamic Banking Theory, Practice and Challenges. Oxford University Press. Kerachi

Idris Awang. 2001. Kaedah Penyelidikan: Suatu Sorotan: Akademi Pengkajian Islam. Universiti Malaya. Kuala Lumpur

J.M Jaco Stein \& R.M. Mersky. 2002. Fundamental of Legal Research. Ed. Ke 8. Foundation Press. New York

K. Zweigert \& H. Kotz. 1987. An Introduction to Comparative Law. Clarendon Press. Oxford

Koenjaraningrat.1977. Metode-metode Penelitian Masyarakat: PT. Gramedia. Jakarta

Kumar Ranjit. 1999. Research Methodology: A Step-by-step Guide for Beginners. Addision Wedley Longman Australia Pty. Limited. Melbourne Lepaulle. 1922. The Functions of Comparative Law (1922) 35 Harv Law Review Muhammad Djumhana. 2003. Hukum Perbankan di Indonesia. Ctk. Ketiga. PT. Citra Aditya Bakti. Bandung 
Muhammad Syafi'i Antonio. 2001. Bank Syariah dari Teori ke Praktik. Ctk. Pertama. Gema Insani Press. Jakarta

Rachmadi Usman. 2010. Aspek-aspek Hukum Perbankan Indonesia. Ctk. Pertama. Gramedia Pustaka Utama. Jakarta

Sidek Mohd. Noah.2000. Reka Bentuk Penyelidikan, Falsafah, Teori dan Praktis: UPM. Serdang

Teungku Muhammad Hasbi Ash Shiddieqy. 1974. Pengantar Fiqih Muamalat. Ctk. Kelima. Bulan Bintang. Jakarta

Wiroso. 2005. Jual-beli Murabaha. UII Press. Yogyakarta

Zaharuddin Abd Rahman. 2009. Murabahah Teori, Aplikasi \& Isu Dalam Perbankan Islam Semasa. True Wealth Publishing. Selangor

Zainuddin Ali. 2008. Hukum Perbankan Syariah. Sinar Grafika. Jakarta

Zamir Iqbal dan Abbas Mirakhor. 2008. Pengantar Keuangan Islam: Teori dan Amalan. terj. oleh A.K. Anwar. Prenada Media Group. Jakarta

\section{B. Other Resources}

"Bay 'al-Murabaha in Islamic Commercial Law". Jurnal Syariah. (Published by Academy of Islamic Studies. University of Malaya. Kuala Lumpur). Vol. 6 (2). January 1998

Banking System in Malaysia: History of Development, Principles and Its Practice)". Jurnal Usuluddin. No. 14. December 2001

\section{Dictionary and Encyclopedia}

Habib Nazir dan Muhammad Hassanuddin. 2004. Ensiklopedi Ekonomi dan Perbankan Syariah. Kaki Langit. Jakarta

Tim Depdikbud. 1989. Kamus Besar Bahasa Indonesia. Ctk. Kedua. PT. Balai Pustaka. Jakarta

Wizaaroh al-Awqof wa al-Syu'un al-Islamiyyah bi al-Kuwait. Tanpa tahun. AlMausu'aat al-Fiqhiyyah, Wizaaroh al-Awqof bi al-Kuwait

\section{Regulations and Legislation}

Undang-Undang No. 8 Tahun 1999 tentang Perlindungan Konsumen

Kitab Undang-Undang Hukum Perdata (KUHPerdata)

Undang-Undang No. 10 Tahun 1998 tentang Perubahan Undang-Undang No. 7

Tahun 1992 tentang Perbankan

Undang-Undang No. 21 Tahun 2008 tentang Perbankan Syariah

Undang-Undang No. 21 Tahun 2011 tentang Otoritas Jasa Keuangan (OJK)

Islamic Banking Act. (IBA)1983 Malaysia, section 2

Banking and Financial Institution Act. (BAFIA), 1989 Malaysia, section 124

Fatwa Dewan Syariah Nasional No: 04/DSN/MUI/IV/2000 tentang Pembiayaan Murabahah 
Concept And Application Of Akad Wakalah In Murabaha Financing In Islamic Banking (A Comparative Study Between Indonesia And Malaysia) 